\title{
Two different neuroimaging patterns in two cases with eclampsia, HELLP syndrome and posterior reversible encephalopathy syndrome
}

\section{Eklampsi, HELLP sendromu ve posterior reversible ensefalopatili iki olgudaki iki farklı nörogörüntüleme paterni}

${ }^{1}$ Aslı Bolayır, ${ }^{2}$ Ali Çetiin

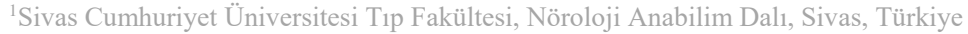

${ }^{2}$ Ali Çetin, İstanbul Haseki Uygulama ve Araştırma Hastanesi, Kadın Hastalıkları ve Doğum Anabilim Dalı, İstanbul, Türkiye Corresponding author: Aslı Bolayır, MD, Sivas Cumhuriyet Üniversitesi Tıp Fakültesi, Nöroloji Anabilim Dalı, Sivas, Türkiye

E-mail: asliarslanturk@gmail.com

Received/Accepted: September 08, 2021 / September 27, 2021

Conflict of interest: There is not a conflict of interest.

\begin{abstract}
SUMMARY
Introduction: Preeclampsia (PE) and eclampsia are two clinical conditions associated with pregnancy. In eclampsia, seizures also occur. One of the complications of eclampsia is HELLP syndrome, a condition characterized by hemolytic anemia, elevated liver enzymes and thrombocytopenia. Preeclampsia and eclampsia are both well-known risk factors for posterior reversible encephalopathy syndrome (PRES), a clinical-radiological syndrome characterized by variable combinations of neurological signs. In this syndrome, typical neuroimaging findings are bilateral symmetric hemispheric edema in parietooccipital regions. However, atypical imaging findings have also been described. Here, we report two different neuroimaging patterns in two cases with PRES associated with eclampsia and HELLP syndrome.

Case: Two pregnant female patients were admitted to our emergency department because of respiratory and neurological symptoms. While the medical history of one of the patients was unremarkable, the other patient was diagnosed with epilepsy and hypertension before pregnancy. Both of them had resistant increased blood pressure and seizures. They underwent urgent caesarean section. In the postoperative period, they were transferred into intensive care unit, necessitating mechanical ventilation because of respiratory failure. Laboratory findings were suggestive of eclampsia and HELLP syndrome and brain imaging findings were suggestive of PRES. Additionally, brain computed tomography scan of one of the patients showed subarachnoid haemorrhage and the magnetic resonance imaging scans of the other patient showed restricted diffusion, indicating cytotoxic edema. The patients were treated with blood transfusions and antihypertensive drugs. Maintenance of normotension resulted in neurological improvement. Subsequently, both of the patients were discharged without neurological sequela.

Discussion and Conclusion: In this article, we reported both the associations between HELLP syndrome, eclampsia and PRES, and two
\end{abstract}


different neuroimaging patterns of PRES. Effective controlling of blood pressure and treatment of HELLP syndrome resulted in complete disappearance of the radiological findings and improvement in the neurological sings.

Keywords: Eclampsia, HELLP syndrome, posterior reversible encephalopathy syndrome

ÖZET

Giriș: Preeklampsi ve eklampsi gebelikle ilişkili iki klinik durumdur. Eklampside nöbetler de olur. Eklampsinin komplikasyonlarından biri hemolitik anemi, yükselmiş karaciğer enzimleri ve trombositopeni ile karakterize olan HELLP sendromudur. Preeklampsi ve eklampsi posterior reversible ensefalopati sendromu (PRES) için iyi bilinen risk faktörleridir. PRES, nörolojik bulguların değişik kombinasyonları ile karakterize bir klinik-radyolojik sendromdur. Bu sendromdaki tipik nörogörüntüleme bulguları pariyetooksipital bölgelerdeki bilateral simetrik hemisferik ödemdir. Ancak atipik görüntüleme bulguları da tanımlanmıştır. Burada eklampsi ve HELLP sendromu ile ilişkili PRES'i olan iki olguda iki farklı nörogörüntüleme paterni bildiriyoruz.

Olgu: İki gebe kadın hasta bize nörolojik ve solunumsal semptomlarla başvurdu. Hastalardan birinin tıbbi öyküsünde özellik yokken, diğer hasta gebelik öncesinde epilepsi ve hipertansiyon tanısı almıştı. Her iki hastanın da kan basınçları dirençli biçimde yüksekti ve nöbetleri vardı. Her iki hastaya da acil olarak sezaryen yapıldı. Postoperatif dönemde her iki hasta da solunum yetmezliği sonucu mekanik ventilasyona gereksinim duyduklarından yoğun bakıma alındı. Hastaların laboratuvar bulguları eklampsi ve HELLP sendromu ile, beyin görüntüleme bulguları ise PRES ile uyumluydu. Ayrıca, olgulardan birinin beyin tomografi tetkiki subaraknoid kanama ve diğer olgunun manyetik rezonans görüntüleme tetkiki ise sitotoksik ödeme işaret eden difüzyon kısıtlanmasını gösterdi. Hastalar kan transfüzyonu ve antihipertansif ilaçlarla tedavi edildiler. Normotansiyonun sağlanması nörolojik iyileşme ile sonuçlandı. Her iki hasta da nörolojik sekel olmaksizin taburcu edildiler.

Tartışma ve Sonuç: Bu makalede, hem HELLP sendromu, eklampsi ve PRES arasındaki ilişkiyi hem de PRES'teki iki farklı nörogörüntüleme paternini bildirdik. Kan basıncının etkin kontrolü ve HELLP sendromunun tedavisi radyolojik bulguların tamamen kaybolması ve nörolojik bulguların düzelmesi ile sonuçlandı.

Anahtar sözcükler: Eklampsi, HELLP sendromu, posterior revesible ensefalopati sendromu

\section{INTRODUCTION}

Preeclampsia (PE), characterized by arterial hypertension, edema and proteinuria, is an important cause of perinatal morbidity and mortality. Eclampsia, a more serious condition, ocures when PE remains untreated. In eclampsia, epileptic seizures are also observed. One of the complications of eclampsia is HELLP syndrome, which consists of microangiopathic hemolytic anemia, elevation of liver enzymes and thrombocytopenia. Pre-eclampsia and eclampsia are one of the well-known risk factors of posterior reversible encephalopathy syndrome (PRES).

PRES is a clinical-radiologic syndrome characterized by variable combinations of focal neurological signs, visual abnormalities, nausea or vomiting, consciousness impairment and headache. In this syndrome, typical neuroimaging manifestations are bilateral symmetric hemispheric edema especially in the parietooccipital corticalsubcortical regions. However, atypical imaging findings such as asymmetry and unilaterality of the lesions, diffusion restriction, contrast enhancement, hemorrhage, and irreversibility have also been described. Here we report two different neuroimaging patterns in two cases with PRES associated with eclampsia and HELLP syndrome.

\section{CASE REPORT}

Case 1

A 44-year-old, gravida three pregnant woman at 31 weeks' gestation (according to her last menstrual period) was admitted to our hospital with acute worsening of dyspnea and orthopnea which had been lasting for three days. There was no known chronic disease or regular drug use in the patient's history. The patient had a total of 3 pregnancies, including this one, with 2 living children and there was no history of similar complaints in previous pregnancies. Physical examination performed in the emergency department revealed dyspnea, tachypnea, and tachycardia without cyanosis. Her oxygen saturation level in the room air was $89 \%$. Because blood pressure of the patient was 240/120 $\mathrm{mmHg}$, intravenous (IV) nitroglycerin was given. Just before she underwent an emergent caesarean section (CS), a generalized tonic-clonic seizure was noted. Therefore, IV magnesium sulphate was given. CS was performed under spinal anesthesia and a healthy male baby was delivered. In the postoperative period, the patient was transferred into the intensive care unit (ICU) necessitating mechanical ventilation because of dyspnea and hypoxemia. During follow-up in the ICU, she had further episodes of seizures, which could be 
controlled after IV administration of phenytoin. Because of the persistence of high blood pressure, IV labetalol and furosemide were given. At that time, neurological examination revealed that the patient was unconscious and unresponsive to painful stimuli, the pupils were reactive to light, however, the fundoscopic examination showed papilledema and the plantar reflexes were bilateral extensor. Laboratory examinations showed proteinuria, increased liver enzymes and low platelet count, which were suggestive of HELLP syndrome. Also, the lactate dehydrogenase and the bilirubin levels were elevated and hemoglobin count was low. Urine specimen demonstrated proteinuria $(+++)$. Prothrombin time and INR levels were within normal limits. A non-enhanced computed tomography (CT) of the brain showed diffuse low attenuation areas, mainly in the subcortical deep white matter of the bilateral parietooccipital lobes and hyperdense areas compatible with subarachnoid hemorrhage in the left superior parietal lobe (Figure 1). Magnetic resonance imaging (MRI) could not be performed because of her unstable condition.

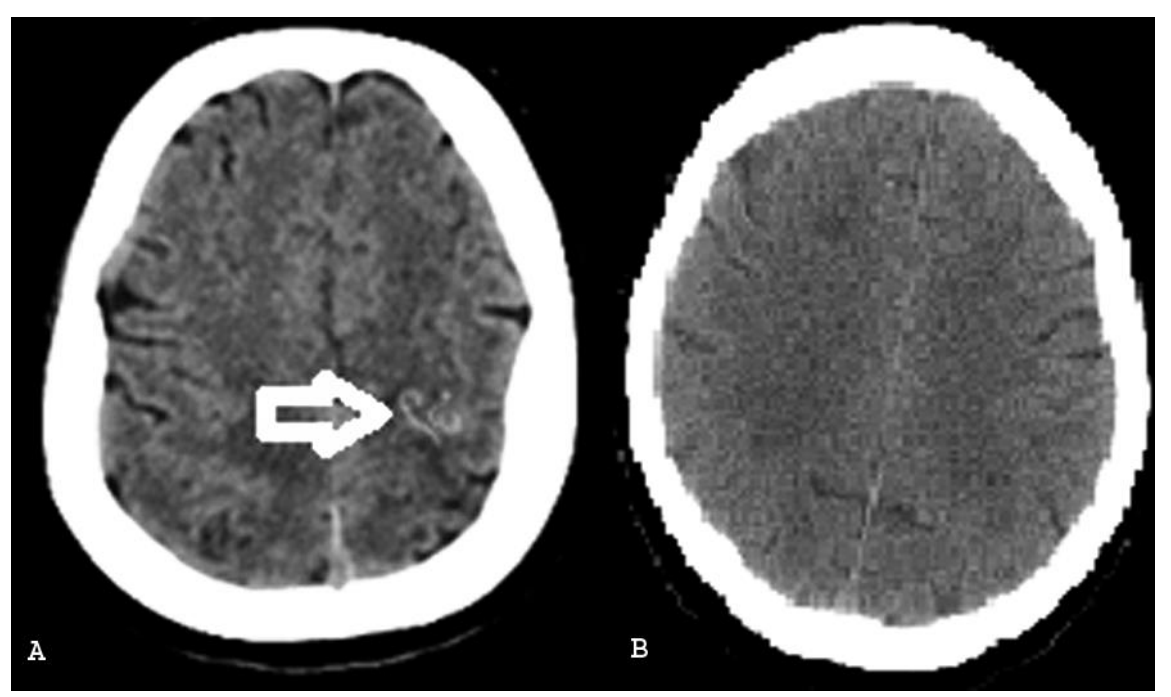

Figure 1: A: A non-enhanced brain computed tomography (CT) of the case 1 showed hyperdense areas compatible with subarachnoid hemorrhage in the left superior parietal lobe (arrow). B: A repeat brain CT showed no abnormal imaging findings.

In addition to fresh frozen plasma, blood and platelet transfusions, the patient was treated with antihypertensive (amlodipin 5mg daily), antiepileptic (phenytoin), and hyperosmolar (mannitol) drugs. After the maintenance of normotension, she showed neurological improvement over the subsequent four days. On the tenth day of the hospitalization, a repeat brain CT was obtained, and no abnormal imaging findings were observed. Then the patient was discharged uneventfully after 15 days of hospitalization without neurological sequela.

Case 2

A 21-year-old primigravida female patient at 31 weeks and 3 days gestation (according to her last menstrual period) was admitted to the emergency department with sudden onset of headache, hypertension and vomiting. Her medical history was remarkable for hypertension and epilepsy diagnosed before pregnancy. The patient's antiepileptic treatment was arranged as levetiracetam $500 \mathrm{mg}$ tb twice a day. The patient did not have any recent seizures and her EEG was normal in the last 6 months. A diagnosis of antepartum PE was made and the patient was treated with an antihypertensive drug (a calcium channel blocker) and then she was transferred to our hospital for further management. Shortly after the admission, the patient underwent emergent CS, which was performed under spinal anesthesia. CS was uneventful and a healthy male baby was delivered. In the postoperative period, while she was being treated with IV magnesium sulphate, the patient presented with a generalized tonic-clonic seizure. The seizure lasted for two minutes and it could be controlled after administration of IV diazepam. Then, she was transferred into the ICU. Neurologic examination, performed a few minutes after the seizure, showed that the patient was in a 
confusional state. She localized the painful stimulus. The plantar reflex was extensor on the right side. At the time of the neurological examination, her blood pressure was 200/130 mmHg. Therefore, IV nitroglycerin was administered. Because of the persistence of high blood pressure, the patient was started on IV labetolol and furosemide. Laboratory analyses showed the elevation of the hepatic transaminases, lactate dehydrogenase and the bilirubins. She had anemia, low platelet and increased white cell counts. Prothrombin time and INR levels were unremarkable. Urine examination showed proteinuria $(+++)$. These findings were suggestive of HELLP syndrome and eclampsia. Brain CT showed a hypodense lesion in the left capsula interna. The MRI of the brain revealed the presence of lesions on T2-weighted and fluid-attenuated inversion recovery (FLAIR) images in the cortical and the subcortical areas of the occipital, parietal and the frontal lobes, cerebellum, basal ganglia, and the brainstem without diffusion restriction, except for the lesion located in the left capsula interna (Figure 2). Blood and platelet transfusions were administered to normalize the hematological abnormalities. On the second day of hospitalization, physical examination revealed dyspnea and tachypnea without cyanosis, blood pressure was $180 / 120 \mathrm{mmHg}$ and she had bilateral crackles at lung bases on auscultation. Arterial oxygen saturation in the room air was $91 \%$. Her chest graph and thorax CT revealed pulmonary edema. Then, endotracheal intubation was performed and the patient was mechanically ventilated with positive pressure ventilation for two days. She was discharged without neurological sequela from the ICU on the twelve days of the admission.

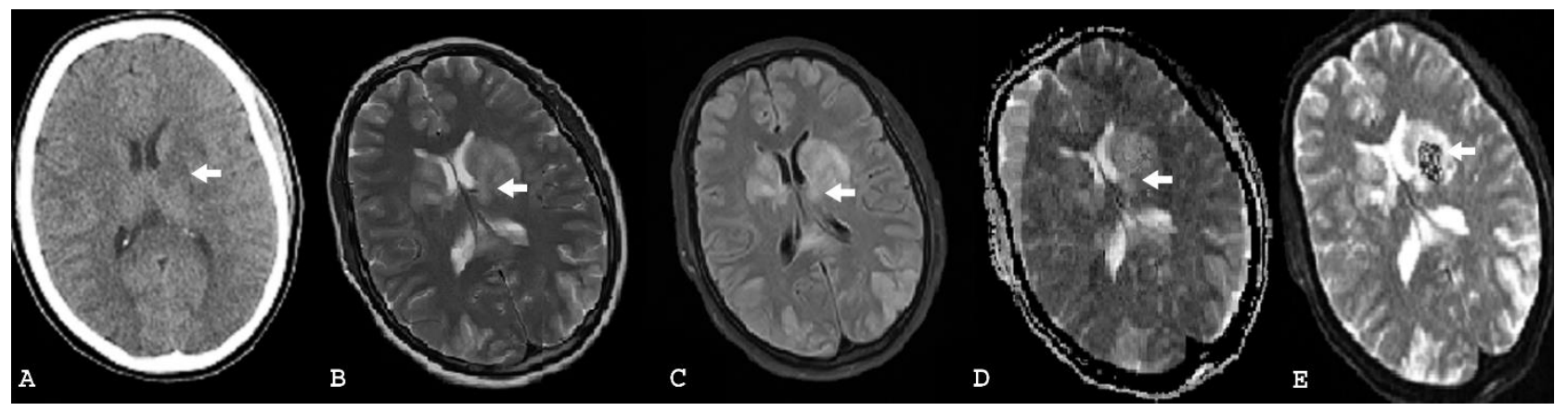

Figure 2: A: Brain CT of the case 2 showed a hypodense lesion in the left capsula interna. B, C. Hyperintense lesions on T2-weighted and FLAIR images in the cortical areas and the basal ganglia D, E. Diffusion restriction in the left capsula interna.

\section{DISCUSSION}

PE remains a leading cause of maternal and perinatal mortality and morbidity. The incidence of PE is $3 \%-7 \%$ of all pregnancies. Symptoms occur especially after the 24th week of pregnancy, as in our patients. The current criteria for diagnosis of $\mathrm{PE}$ are systolic blood pressure (SBP) $\geq 140 \mathrm{mmHg}$ or diastolic blood pressure (DBP) $\geq 90 \mathrm{mmHg}$ with proteinuria of $\geq 0.3 \mathrm{~g} /$ day ${ }^{1}$. Clinical and laboratory tests are useful to determine the severity of PE. Eclampsia, the major neurological complication of $\mathrm{PE}$, is characterized by epileptic seizures or varying degrees of consciousness impairment ${ }^{1}$. PE and eclampsia play an important role of death in pregnancy. Delivery is the single curative treatment for PE.

HELLP syndrome, consists of microangiopathic hemolytic anemia, elevated liver enzymes and thrombocytopenia, is one of the complications of eclampsia. While hematologic [intravascular disseminated coagulation] and cardiopulmonary events [pulmonary edema, acute cardiac insufficiency] are often accompanied by this syndrome, neurological impairments [cerebral bleeding, hypoxic-ischemic encephalopathy] are observed in only $4.5 \%$ of the patients ${ }^{2}$. Previous studies showed that endothelium dysfunctions or the vasoactive mechanism with loss of the cerebral vascular autoregulation can be important in the pathogenesis of this syndrome ${ }^{3}$. So, hypertensive encephalopathy and eclampsia might share similar pathophysiological mechanisms ${ }^{4}$.

PRES is a clinical-radiologic entity. It can develop at any age from 4 to 90 years, with a female predominance ${ }^{4}$. Characteristic features of PRES are variable combinations of seizures, visual abnormalities, nausea or vomiting, consciousness 
impairment, headache and focal neurological signs; it may also be complicated by stroke ${ }^{4}$. Etiological factors include hypertension (61\%), cytotoxic medications $(19 \%)$, preeclampsia or eclampsia (6\%), and autoimmune and systemic disorders including sepsis ${ }^{5}$. Our patients had acute elevation of blood pressure and eclampsia which might have triggered the syndrome. Two reverse theories have been proposed to understand the pathophysiology of PRES ${ }^{6,7}$. Because both vasogenic and cytotoxic edema, as well as hypoperfusion or hyperperfusion could occur in PRES, endothelial dysfunction seems to better account for the mechanisms of PRES ${ }^{7}$. While forced dilation of cerebral arteries and disruption of the integrity of the blood brain barrier could be the most important mechanisms in occurrence of vasogenic edema observed in patients with PRES and hypertension, ischemia triggered by systemic inflammation, endothelial injury and vascular dysfunction, active leakage of fluid due to other processes affecting the vascular wall are also suggested to contribute to vasogenic edema. Abnormal parenchymal contrast enhancement ,typically seen only with injury to the blood brain barrier, has been reported to occur in 21-38\% of patients with PRES ${ }^{8}$.

In PRES, typical neuroimaging manifestations are bilateral symmetric areas of hemispheric edema especially in the parietooccipital corticalsubcortical regions (98\%). Contrast enhancement or restricted diffusion usually do not be observed ${ }^{10}$. According to clinical observation, the vascular system in the anterior region of the brain have more dense sympathetic innervations than the posterior regions. These may at least partially explain the predilection for edema in the posterior regions of the brain ${ }^{10,11}$. However, frontal lobe (68\%), temporal lobe $(40 \%)$, cerebellum $(30 \%)$, basal ganglia, brain stem, and deep white matter may also be involved. The MRI of our second case revealed hyperintense lesions in the cerebellum, basal ganglia, brainstem and the frontal and the temporal lobes on T2-weighted and FLAIR images. Atypical imaging manifastation like unusual localization, asymmetry and unilaterality of the lesions, diffusion restriction, contrast enhancement, hemorrhage, and irreversibility have also been described ${ }^{10-12}$. MRI images typically show vasogenic edema in the subcortical white matter and the cortex, Although T2-weighted imaging or FLAIR images demonstrate hyperintense lesions in the region of vasogenic edema, DWI most commonly shows isointense lesions. Diffusion restriction, which indicates mostly irreversible process, has been described in $17-26 \%$ of patients with PRES ${ }^{10,12}$. Cytotoxic edema with massive vasogenic edema is found in a relatively lower proportion of patients with PRES and it can be differentiated from vasogenic edema by using DWI. Our second case had diffusion restriction in the left capsula interna. With early detection of the cytotoxic edema it might be prevented vasogenic edema from progressing into irreversible insult.

As the reported rate of intracranial hemorrhage, which could present as intraparenchymal hematoma, sulcal subarachnoid hemorrhage, and minute hemorrhages, is $5-17 \%$ on $\mathrm{CT}$ and conventional MRI in PRES ${ }^{10,12}$, the incidence of microhemorrhages is much higher $(60 \%)$ with susceptibility-weighted images ${ }^{12}$. Brain CT of our first case showed sulcal subarachnoid hemorrhage in the left superior parietal lobe.

As a result, in this article, we reported the associations between HELLP syndrome, eclampsia and PRES and two different imaging patterns of PRES. The effective and fast correction of blood pressure levels, associated with the quick recognition and treatment of HELLP syndrome and PRES resulted in good outcomes and total reversibility of the sings, as previously suggested by the medical literature.

\section{REFERENCES}

1. Bartynski WS. Posterior reversible encephalopathy syndrome, part 1: fundamental imaging and clinical features. American Journal of Neuroradiology. 2008;(29):1036-42.

2. Bartynski WS. Posterior reversible encephalopathy syndrome, part 2: controversies surrounding pathophysiology of vasogenic edema. American Journal of Neuroradiology. 2008;(29):1043-49.

3. Burnett MM, Hess CP, Roberts JP, Bass NM, Douglas VC, Josephson SA. Presentation of reversible posterior leukoencephalopathy syndrome in patients on calcineurin inhibitors. Clinical Neurology and Neurosurgery. 2010;(112):886-89.

4. Hefzy HM, Bartynski WS, Boardman JF, Lacomis D. Hemorrhage in posterior reversible encephalopathy syndrome: imaging and clinical features. AJNR Am J Neuroradiol 2009;30:1371-9.

5. Hinchey J, Chaves C, Appignani B, Breen J, Pao L, Wang A, Pessin MS, Lamy C, Mas JL, Caplan LR. A reversible posterior leukoencephalopathy syndrome. N Engl J Med 1996;334:494- 500.

6. Hugonnet E, Da Ines D, Boby H, Claise B, Petitcolin V, Lannareix V, Garcier JM. Posterior 
reversible encephalopathy syndrome (PRES): features on $\mathrm{CT}$ and MR imaging. Diagn Interv Imaging 2013;94:45-52.

7. Lee VH, Wijdicks EF, Manno EM, Rabinstein AA. Clinical spectrum of reversible posterior leukoencephalopathy syndrome. Archives of neurology. 2008;(21):205-10.

8.Legriel S, Pico F, Azoulay E. Understanding posterior reversible encephalopathy syndrome. Annual Update in Intensive Care and Emergency Medicine.2011;(112):631-53.

9.Marra A, Vargas M, Striano P, Del Guercio L, Buonanno P, Servillo G. Posterior reversible encephalopathy syndrome: the endothelial hypotheses. Med Hypotheses 2014;82:619-22.
10.McKinney AM, Sarikaya B, Gustafson C, Truwit CL. Detection of microhemorrhage in posterior reversible encephalopathy syndrome using susceptibility-weighted imaging. AJNR Am J Neuroradiol 2012;33:896-903.

11.McKinney AM, Short J, Truwit CL, Mc Kinney ZJ, Kozak OS, Santa Cruz KS, Teksam M. Posterior reversible encephalopathy syndrome: incidence of atypical regions of involvement and imaging findings. AJR Am J Roentgenol 2007;189:904-912.

12.Negro A, Zuccoli G, Regolisti G, Mastrangeli S, Rossi E. Reversible posterior leukoencephalopathy associated with postpartum HELLP syndrome. Eur J Intern Med 2005;16:291-293. 